\title{
Analysis of the Biological Features of the Blue Tilapia, Oreochromis aureus in the Garmat Ali River, Basrah, Iraq
}

\author{
Sara M. Al-Wan ${ }^{1}$ and Abdul-Razak M. Mohamed ${ }^{2 *}$ \\ ${ }^{1}$ Basrah Agriculture Directorate \\ Ministry of Agriculture, Iraq \\ ${ }^{2}$ Department of Fisheries and Marine Resources, College of Agriculture \\ University of Basrah, Iraq \\ "Corresponding author's email: abdul19532001 [AT] yahoo.com
}

\begin{abstract}
The blue tilapia, Oreochromis aureus (Steindachner, 1864) is exotic fish and became widely distributed throughout different natural waters of Iraq during the last years. The present study describes the length compositions, age, growth, reproduction and food habit of the species in the Garmat Ali River from September 2018 to August 2019. A total of 1050 specimens were caught using gill nets, cast net, and electrofishing. The lengths of $O$. aureus ranged from 6.6 to $22.9 \mathrm{~cm}$, and the most dominant lengths were 14.0 to 18.0 cm representing $61.6 \%$ of the catch. A positive allometric growth pattern was observed for males $(b=3.317)$, females $(b=3.231)$ and all individuals $(b=3.283)$. There were three peaks for relative condition factor $\left(K_{n}\right)$ that appeared during October, April, and July for both sexes. The age estimated on the basis of scales showed that the population comprised of 1 to 5 years. The parameters of the von Bertalanffy growth curve were L $\infty=27.6$ $\mathrm{cm}, K=0.193$ and $t_{0}=1.18$. The growth performance index ( $($ ) of $O$. aureus was computed as 2.17. The overall sex ratio (male: female) was 1:1.04. Females attained sexual maturity at a lower size than males with mean size at first maturity determined as $6.6 \mathrm{~cm}$ for females and $9.2 \mathrm{~cm}$ for males. Two peaks of the gonado-somatic index were shown, the higher one in April and the lower one in September in both sexes. The estimated fecundity ranged from 352 to 1033 eggs in the fish ranging from 12.2 to $20.5 \mathrm{~cm}$ in length. O. aureus is an opportunistic feeder that will successfully utilize whatever food source is available, its diet comprised of detritus $(43.1 \%)$, diatoms (23.9\%), algae (22.8\%), macrophytes (7.1\%) and crustaceans (6.0\%). The results highlighted basic biological features on invasion fish species which can assist in fisheries management and conservation of the fish species in Iraqi waters.
\end{abstract}

Keywords-- Blue tilapia, age and growth, reproduction, food habit, Garmat Ali River, Iraq

\section{INTRODUCTION}

Oreochromis aureus (Steindachner, 1864), commonly known as blue tilapia is a species of fish in the Cichlidae family. The members of this family are generally known as tilapia (Cichlid). Tilapia is native to northern and western Africa, the Middle East, central and south America, and southern India [1]. This family represented 250 genera and 1720 valid species [2]. Tilapia consists of three important genera namely Oreochromis, Sarotherodon and Coptodon (Tilapia), each includes many species including blue tilapia O. aureus, nile tilapia Oreochromis niloticus, gililean tilapia (Sarotherodon galilaeus) and redbelly tilapia Coptodon zillii [3]. All tilapia species are nest builders; fertilized eggs are guarded in the nest by a brooding parent. Species of both Sarotherodon and Oreochromis are mouth brooders; eggs are fertilized in the nest but parents immediately pick up the eggs in their mouths and hold them through incubation and for several days after hatching. In Oreochromis species, only females practice mouth brooding, while in Sarotherodon species either the male or both male and female are mouthbreeders [4].

O. aureus has mainly been introduced into different waters through stocking, but also via aquaculture and aquatic vegetation control. It is reared widely all over the world, and escapes or releases from aquaculture facilities, zoological parks, and aquariums are common [5]. O. aureus is primarily a fresh and brackish water fish that occurs in a wide range of habitats such as streams, rivers, lakes, and ponds, but it has a high tolerance for saltwater at up to $20 \%$. The lower lethal water temperature for most tilapia species is $10-11^{\circ} \mathrm{C}$ for a few days, but the $O$. aureus tolerates temperatures to about $8^{\circ} \mathrm{C}[4]$. 
Tilapia species are exotic fish to Iraqi waters and early records show that Tilapia (Coptodon) zilli was present in the Euphrates River near Musaib City, Centre of Iraq [6, 7]. Later two cichlids species, C. zilli and O. aureus were recorded further south in the main outfall drain, Basrah [8] and O. niloticus in the Shatt Al-Arab River [9], and became widely distributed in different natural waters of the country [10-13].

O. aureus now well established and easily becomes one of the dominant species in some Iraqi waters. The species constituted $12.58 \%$ of fish assembly in the Shatt Al-Arab River [14], 2.64\% of the fish assemblage in Garmat Ali River [15], 11.42\% of fish assemblage in the Al-Diwaniya River, middle of Iraq [16], 18.86\% of fish structure in the Al-Swab River, a tributary of Shatt Al-Arab River [17] and $11.7 \%$ of fish assemblage in the middle part of Shatt Al-Arab River [18].

Some biological characteristics of $O$. aureus have been carried out by several investigators in different natural waters of the world [19-26,1]. In Iraq, the growth and food habits of $O$. aureus have been investigated in some waters. [27, 28] studied the food habit of O. aureus in the north of Shatt Al-Arab River and Chybayish marsh, respectively. [29] described the growth of $O$. aureus in the Euphrates River at the Al-Hindia barrier, middle of Iraq. [30] investigated the trophic interaction of $O$. aureus with two other cichlids species in the Euphrates River. [31] studied the food habit and growth of $O$. aureus in the Tigris River, south of Baghdad.

The aim of this study was to collect information on age, growth, length-weight relationship, relative condition factor, sex ratio, gonado-somatic index, fecundity and food habit of $O$. aureus collected from Garmat Ali River, south Iraq for the first time, in order to investigate the causes of its rapid spread in this waters and to gather data on which to design a plan for the control of this exotic species.

\section{MATERIALS AND METHOD}

The study area includes the Garmat Ali River, a waterway that connects the East Hammar marsh to the Shatt Al-Arab River, situated in the north of Basrah city (Fig. 1). Its length is about $6 \mathrm{~km}$ with a width of $280 \mathrm{~m}$ and mean depth of $9 \mathrm{~m}$. The river is affected by the tidal current of the Arabian Gulf through the Shatt Al-Arab River. The predominant vegetation on the banks was Phragmites australis and Typha domingensis, whereas Ceratophyllum demersum was dominant in the deeper areas. Samples were collected monthly along the river from September 2018 to August 2019.

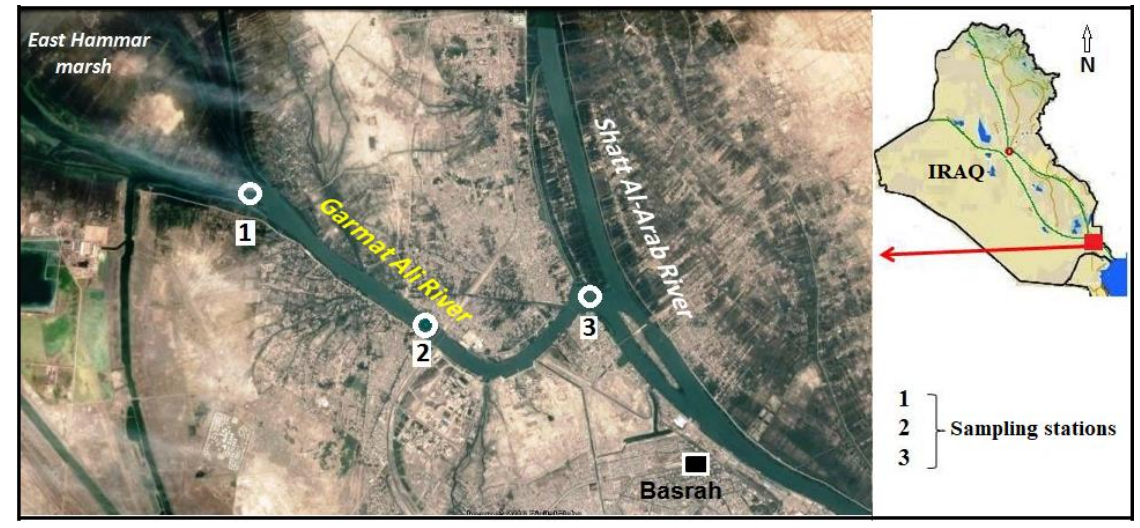

Figure 1: Map of the Garmat Ali River with locations of study sites.

Fish were caught by drifted gill nets (200-500 m length, with $15 \times 35 \mathrm{~mm}$ mesh size), fixed gill nets (100-300 m length, with 15x35 mm, mesh size), cast net ( 9 m diameter, with 15x15 mm mesh size) and electro-fishing by generator engine (providing 300-400V and 10A). After capture, the fish were preserved in an icebox for subsequent analysis.

In the laboratory, fish were identified and weighed to the nearest $\mathrm{g}$ and measured to the nearest $0.1 \mathrm{~cm}$ total length individually. Scales were extracted from a standard area between the lateral line and dorsal fin of the fish, cleaned, dried and mounted between two glass microscope slides for age estimation. Fish were then dissected and the stomachs were removed and preserved in $4 \%$ formaldehyde. Gonads were subsequently removed from the body cavity and weighed. Sex was determined by macroscopic observation of the gonads. To determine the absolute fecundity of the fish, ovaries of 18 matured ovaries with visible eggs were preserved in Gilson fluid during March-April 2019, and the estimation of fecundity based on the gravimetric method [32]. Absolute fecundity was estimated by weighing all the eggs in the ovary and also by counting three subsamples of eggs from different parts of the ovary. The regression of fecundity on both length and weight was calculated. 
The length-weight relationship was determined by applying the equation $\mathrm{W}=\alpha \mathrm{L}^{\mathrm{b}}$, where $\mathrm{W}$ is the total body weight $(\mathrm{g}), \mathrm{L}$ is the total length $(\mathrm{cm}), \alpha$ is the intercept and $\mathrm{b}$ is the slope [33]. The Student t-test was used to compare the value of the slope (b) with 3 [34]. The relative condition factor $\left(\mathrm{K}_{\mathrm{n}}\right)$ was estimated using the following formula, $\mathrm{K}_{\mathrm{n}}=\mathrm{W}^{\mathrm{e}} / \mathrm{W}$ [33], where $\mathrm{W}^{\mathrm{ee}}=$ the observed weight of each individual and $\mathrm{W}=$ the expected weight using the length-weight relationship.

Scales were examined using a micro-projector (magnification 20X) to age determination, and to measure the total scale radius and the distance from the focus to each annulus. The body-scale relationship was best described by the linear equation $\mathrm{L}=\mathrm{a}+\mathrm{bS}$ where $\mathrm{L}$ is the total fish length in $\mathrm{cm}, \mathrm{S}$ is the scale radius in $\mathrm{cm}$ and $\mathrm{a}$ is the intercept on the $y$-axis and $b$ the slope of the regression line. Hence, the lengths were back-calculated with the equation $L_{n}=a+S_{n} / S(L-a)$ [35], where $L_{n}$ is the length of the fish at age ' $n$ ', a is the intercept with the axis of the abscissa of the previous regression, $S_{n}$ is the radius of the annulus ' $n$ ', $S$ is the scale radius at capture and $L$ is the length at capture.

The von Bertalanffy growth equation for length was fitted to the back-calculated mean lengths using Beverton and Holt method [34]: $\mathrm{L}_{t}=\mathrm{L}_{\infty}\left(1-\mathrm{e}^{-\mathrm{K}(\mathrm{t}-\mathrm{to})}\right)$, where $\mathrm{L}_{\mathrm{t}}$ is total length at age $\mathrm{t}, \mathrm{L}_{\infty}$ is asymptotic length, $\mathrm{K}$ is the growth coefficient and $t_{o}$ is hypothetical age at which the length is zero. Based on von Bertalanffy growth parameters, the performance index $(\varnothing)$ was calculated as $\varnothing=\log _{10} \mathrm{~K}+2 \log _{10} \mathrm{~L}_{\infty}[36]$.

The sex ratio compared to 1:1 using a Chi-square test $(\chi 2)$. The mean size at first maturity was taken as that at which $50 \%$ of individuals were mature. The gonado-somatic index (GSI) was calculated by expressing the gonad mass as a percentage of body mass [37]: GSI= gonad weight/body weight $\times 100$

Later, stomach was opened, gives the degree of fullness, and then emptied into a Petri dish to examine different food items using a research microscope. The stomachs were scored $0,5,10,15$ and 20 points according to its fullness as described by [38]. The feeding index was determined after [39]. The vacuity index was calculated as the number of empty stomachs divided by the number of stomachs analyzed [40]. The different food items were identified according to [41], [42] and [43]. The results were analyzed by employing two methods, the percentage of points $(\mathrm{P} \%)$ and frequency of occurrence $(\mathrm{O} \%)$ methods [44]. An estimate of the index of relative importance (IRI\%) of each food category was obtained by combined the two methods [45]:

$$
\mathrm{IRI}=\mathrm{O} \% \times \mathrm{P} \% \text { and IRI } \%=\mathrm{IRI} / \Sigma \text { IRI } * 100
$$

The obtained data were analysed using the computer programmed Microsoft Excel, ver., 2010.

\section{RESULTS}

\subsection{Seasonal variations in length-frequency distributions}

Figure (2) shows the seasonal length-frequency distributions of $O$. aureus in the present study. The sample composed of 1050 specimens, ranged from 6.6 to $22.9 \mathrm{~cm}$ in total length, the smallest fish was caught in March (spring) and the largest one in August (summer). The smallest fish caught during autumn was $12.0 \mathrm{~cm}$ and the largest one was $22.3 \mathrm{~cm}$. The highest frequency of catches belonged to the length group $17 \mathrm{~cm}$ constituting $22.4 \%$, while the length groups from 15 to $19 \mathrm{~cm}$ prevailed the catch and formed $77.1 \%$. Lengths of fish during winter ranged from 7.8 to $21.0 \mathrm{~cm}$, and the most dominant length groups observed were those of 9 to $11 \mathrm{~cm}$ representing $41.1 \%$ of the catch, while sizes 14 to $16 \mathrm{~cm}$ accounted for $33.3 \%$. The small fish caught during spring was $6.6 \mathrm{~cm}$ and the large one was $20.5 \mathrm{~cm}$. The fish lengths 12 to $15 \mathrm{~cm}$ comprised 56.1 of the catch during this season. Sizes of $O$. aureus during summer ranged from 12.7 to $22.9 \mathrm{~cm}$, and the dominant length group was $16 \mathrm{~cm}$, formed $20.4 \%$ of the catch in this season, while the length groups 14.0 to $18.0 \mathrm{~cm}$ constituted $81.5 \%$. The overall lengths of $O$. aureus ranged from 6.6 to $22.9 \mathrm{~cm}$, and the most dominant length groups observed were those of 14.0 to 18.0 $\mathrm{cm}$ representing $61.6 \%$ of the total number.

\subsection{Length-weight relationship and relative condition factor}

The graphical representation of the estimated length-weight relationships for females, males and all individuals of $O$. aureus is given in Figure 3. Using a t-test for equality of two regression coefficient, a significant difference $(\mathrm{t}=3.7, \mathrm{p}<0.05)$ of growth was observed in males and females. Thus this suggested the use of one model for males and another for females. The descriptive statistics for the calculation of length-weight relationships of all groups are presented in Table 1 . The statistical test of $b=3$ being statistically significant, indicating positive allometric growth for all groups. Also, the corresponding significant correlation coefficients $\left(r^{2}\right)$ indicating a length-weight relationship (in log scale) strongly linear in all the cases.

Monthly changes relating to the mean relative condition factor $\left(\mathrm{K}_{\mathrm{n}}\right)$ of $O$. aureus were determined for each sex (Fig. 4), although there are no significant differences in the relative condition index $(\mathrm{Kn})$ between them $(\mathrm{t}=$ $0.02, \mathrm{p}>0.05)$. The mean values of $\mathrm{K}_{\mathrm{n}}$ for males and females were $1.00 \pm 0.03$ and $1.00 \pm 0.05$, respectively. The 
highest values of $\mathrm{K}_{\mathrm{n}}$ for males and females were in July, 1.07 and 1.12, respectively, while, the minimum values of $\mathrm{K}_{\mathrm{n}}$ for all individuals were in February, 0.95 and 0.92, respectively. However, there are three peaks for relative condition factor observed in October, April, and July for both sexes.

\subsection{The age composition and growth}

The relationship between the fish length (L) and the scale radius (S) of O. aureus fitted to a linear model (Fig. 5), which was $\mathrm{L}=2.497+5.767 \mathrm{~S}, \mathrm{r}^{2}=0.985$. The estimated age ranged from 1 to 5 years. Ages 2 and 3


Figure 2: Seasonal length-frequency distributions of $O$. aureus

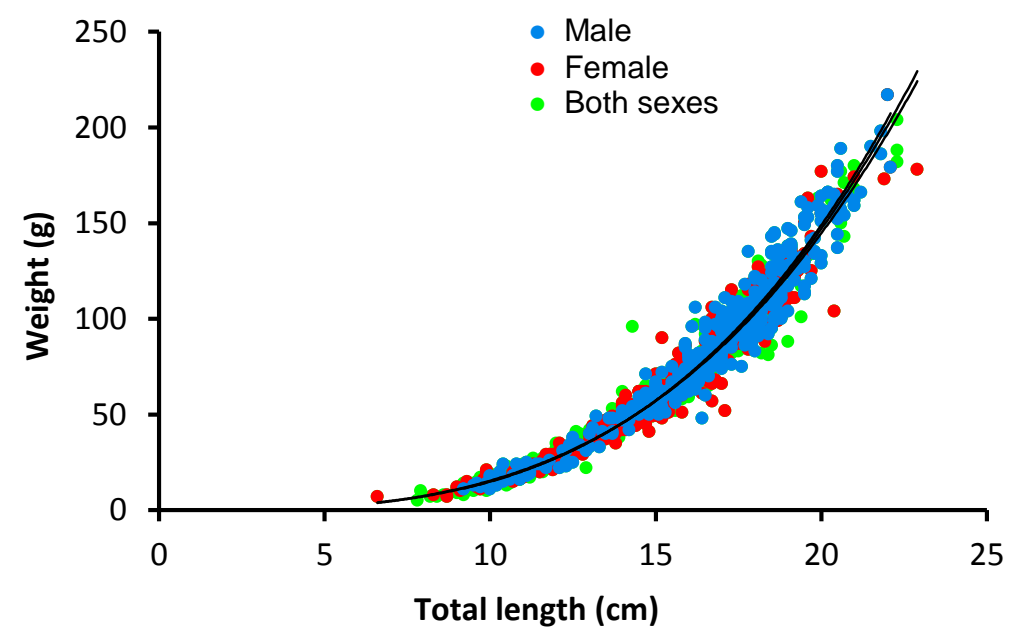

Figure 3: The length-weight relationships of males, females and all individuals of $O$. aureus

Table 1: The descriptive statistics of length-weight relationships of $O$. aureus

\begin{tabular}{llccccccc}
\hline & \multicolumn{4}{c}{ Total length (TL, cm) } & \multicolumn{3}{c}{ Regression coefficient } \\
Sex & $\mathbf{N}$ & Mean \pm S.D & Min. & Max. & a & b & $\mathbf{r}^{\mathbf{2}}$ & t-test \\
\hline Male & 370 & $16.6 \pm 2.776$ & 9.2 & 22.1 & 0.0073 & 3.3171 & 0.9676 & $10.019^{*}$ \\
Female & 386 & $15.3 \pm 2.456$ & 6.6 & 22.9 & 0.0079 & 3.2313 & 0.9654 & $7.4076^{*}$ \\
All individuals & 1050 & $15.3 \pm 3.023$ & 6.6 & 22.9 & 0.0079 & 3.2834 & 0.9710 & $16.165^{*}$ \\
\hline
\end{tabular}

Note: $\mathrm{N}=$ sample size; $\mathrm{S} . \mathrm{D}=$ standard deviation;: ${ }^{*}$-test is significant, $\mathrm{p}<0.05$ 


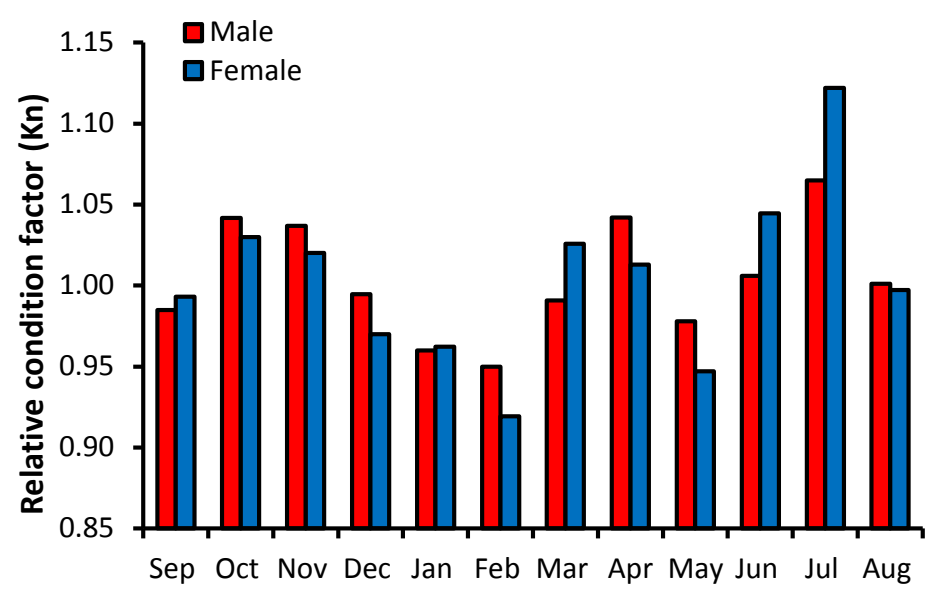

Figure 4: Monthly variations in relative condition factor of $O$. aureus

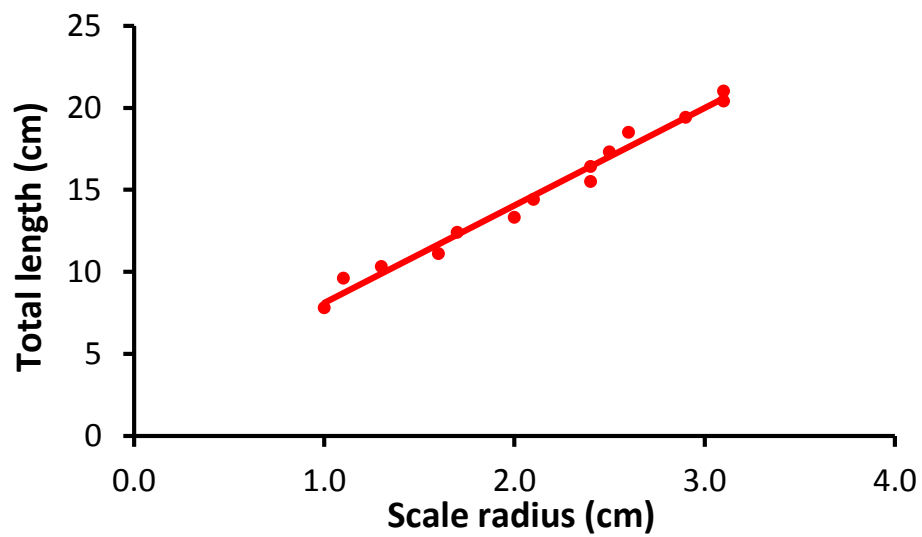

Figure 5: The relationship between fish length and scale radius of $O$. aureus

were the most numerous both for the total population (62.7\%) and 23.1, 12.1 and $2.2 \%$ for ages 1,4 and 5 , respectively. The mean size of fish at the time of formation of the first annulus was $\mathrm{TL}=2.5 \mathrm{~cm}$.

The average back-calculated lengths of the pooled data at different age classes have been calculated as given in Table 2. The mean lengths estimated at ages 1 to 5 years were found to be 9.5, 12.6, 15.3, 17.5 and $19.2 \mathrm{~cm}$, respectively. The back-calculated length at annulus formation suggested that $O$. aureus increased in length by $49.4 \%$ in age 1 and $9.1 \%$ at age 5 .

Using back-calculated lengths at age (Table 2), we estimated the von Bertalanffy growth equation parameters as follows:

$$
\mathrm{L}_{\mathrm{t}}=27.6\left(1-\mathrm{e}^{(-0.193(\mathrm{t}+1.18)}\right)
$$

The growth performance index $(\varnothing)$ of $O$. aureus was calculated as 2.17

Table 2: Mean back-calculated total lengths at age of $O$. aureus

\begin{tabular}{ccccccc}
\hline \multirow{2}{*}{ Age } & \multicolumn{9}{c}{ Length at age (cm) } & \multirow{2}{*}{$\begin{array}{c}\text { No. of } \\
\text { fish }\end{array}$} \\
\cline { 2 - 6 } & $\mathbf{1}$ & $\mathbf{2}$ & $\mathbf{3}$ & $\mathbf{4}$ & $\mathbf{5}$ & 21 \\
2 & 10.5 & & & & & 27 \\
3 & 9.6 & 13.0 & & & & 30 \\
4 & 8.7 & 12.7 & 15.6 & & & 11 \\
5 & 9.9 & 13.6 & 16.5 & 18.7 & & 2 \\
Mean length (cm) & 8.6 & 11.0 & 13.9 & 16.2 & 19.2 & \\
Annual increment (cm) & 9.5 & 12.6 & 15.3 & 17.5 & 19.2 & \\
\% Growth increment & 9.3 & 3.1 & 2.8 & 2.1 & 1.8 & \\
\hline
\end{tabular}




\subsection{Reproduction}

In the study, a total of 756 fish from O. aureus were analyzed, $386(51.1 \%)$ were female and $370(48.9 \%)$ were males. Females were more abundant than males throughout the year except in September, November, and May-July. The overall sex ratio was 1:1.04 (male: female), and did not differ significantly of the sex ratio 1:1 ( $X^{2}$ $=0.34, \mathrm{P}>0.05)$. No fish less than $6.6 \mathrm{~cm}$ was caught, and this fish was female at the maturity stage. Also, the smallest male $(9.2 \mathrm{~cm})$ in the samples was sexually mature.

The GSI value of male O. aureus ranged from 0.07 in February to 2.92 in April (Fig. 6). Fish caught from October to January having low GSI values. For females, the GSI values varied from 0.23 in November and July to 9.11 in March. Low GSI values were observed in the months of October to February and July. Two peaks of the gonado-somatic index were shown, the higher one in April thereafter as a sign of the continuous release of eggs, and the second in September in both sexes (Fig. 6).
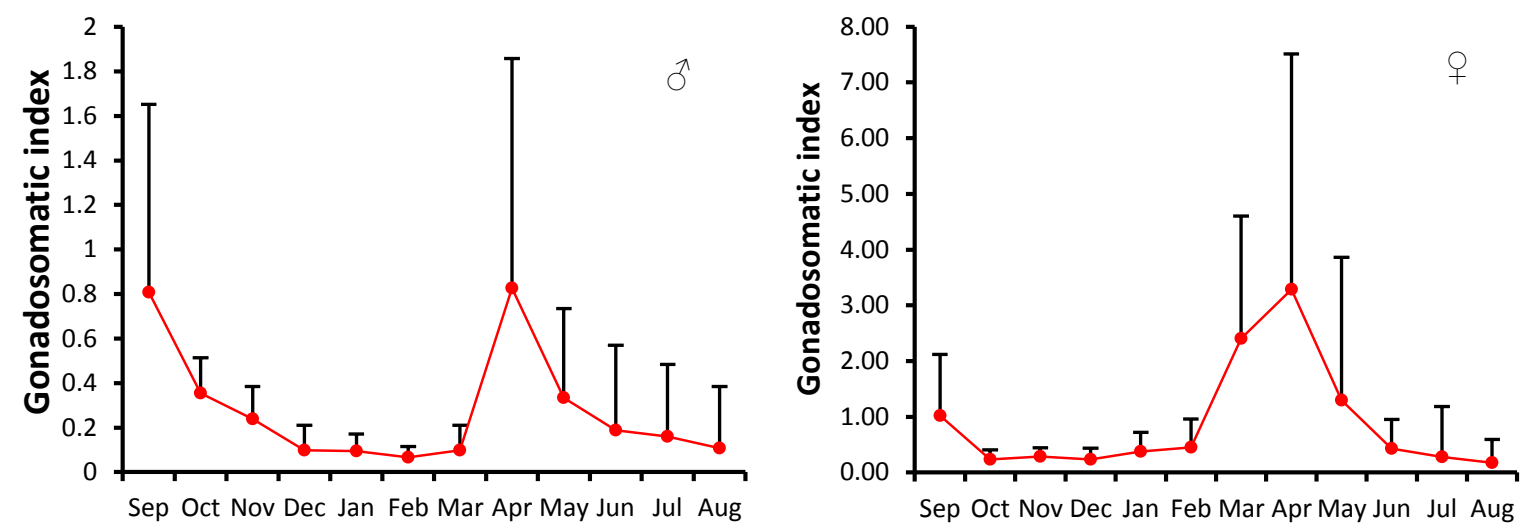

Figure 6: Monthly variations in the GSI of $O$. aureus

A total of 18 gravid females of $O$. aureus were examined for its fecundity. The fecundity ranged between 352 to 1033 eggs, with a mean value of $759 \pm 193.8$ in the fish ranging from 12.2 to $20.5 \mathrm{~cm}$ in length and $29 \mathrm{gt} 165 \mathrm{~g}$ in weight. Various relationships between fecundity and body parameters (fish length and body weight) were worked out and it was observed that the curvilinear relationship was the best representative and exhibited better correlations. The relationships revealed significant positive correlations, and best represented for both by the following equations:

$$
\begin{gathered}
F=3.66 \mathrm{~L}^{2.0},\left(\mathrm{r}^{2}=0.710\right) . \\
\mathrm{F}=72.42 \mathrm{~W}^{0.6},\left(\mathrm{r}^{2}=0.726\right) .
\end{gathered}
$$

\subsection{Food habit}

Figure (7) shows monthly fluctuations in the feeding and vacuity indices of $O$. aureus in the River. Out of the 543 specimens of the species examined, 259 (47.7\%) has food in their stomachs. The feeding index of $O$. aureus ranged from $6.1 \%$ in August to $67.0 \%$ in March. The highest percentage of empty stomachs for the species was recorded during summer. The vacuity index of the species fluctuated from $16.7 \%$ in September to $85.0 \%$ in August.

Monthly differences in index of relative importance (IRI) of $O$. aureus for food items that represented more than $5 \%$ relative importance were considered to be major food items in the diet of the species is shown in Figure 8. The diet of $O$. aureus was constituted from five groups: detritus, algae, diatoms, macrophytes, and crustaceans. Minor food items observed in the specimens were aquatic insects, fish eggs and zooplankton. Detritus were the dominant item in the diet of $O$. aureus during eight months and the percentage contribution according to the index of relative importance (IRI) ranged from $14.9 \%$ in May to $76.5 \%$ in August. Diatoms occupied the second position, prevailing for three months and ranged from $0.5 \%$ in September to $48.1 \%$ in February. Algae came to the third position and ranged from $8.0 \%$ in August 


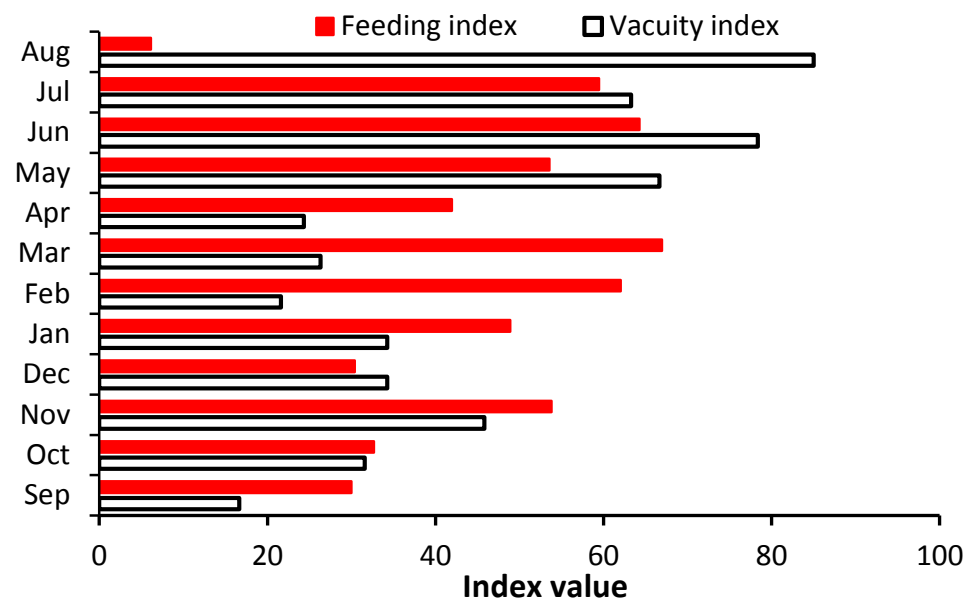

Figure 7: Monthly variations in feeding and vacuity indices of $O$. aureus

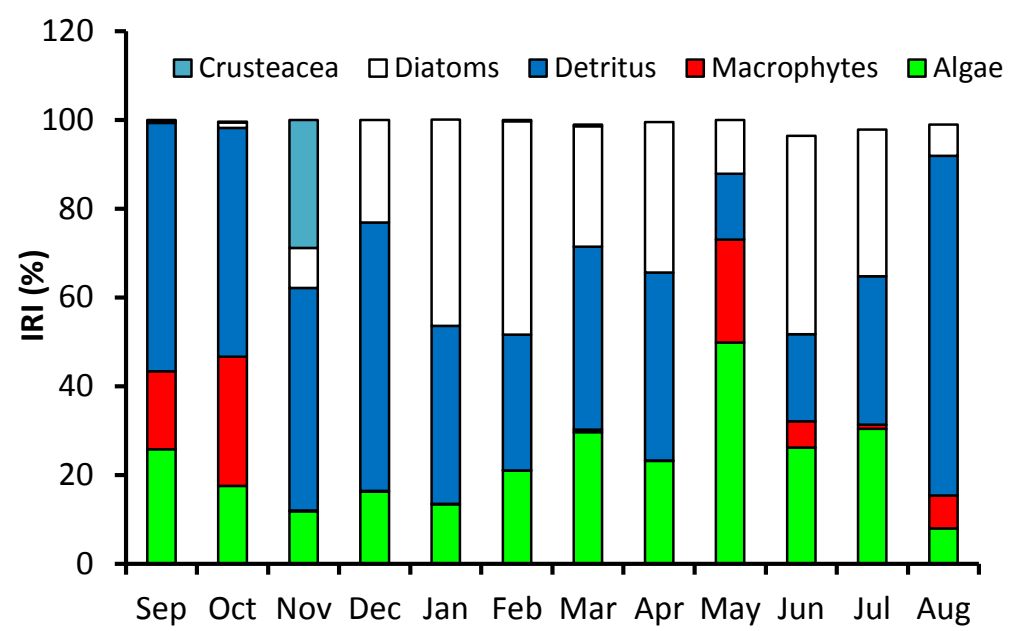

Figure 8: Monthly changes in the relative importance index (IRI\%) of food items of $O$. aureus

to $49.9 \%$ in May. The contribution of crustaceans in the diet fluctuated from $0.2 \%$ in October to $28.9 \%$ in November. The overall diet composition of $O$. aureus was comprised of detritus (43.1\%), diatoms (23.9\%), algae $(22.8 \%)$, macrophytes $(7.1 \%)$ and crustaceans $(6.0 \%)$.

\section{DISCUSSION}

The size of $O$. aureus found in the present study $(6.6$ to $22.9 \mathrm{~cm})$ was similar those found by [22]in Wadi El-Raiyan Lakes, Egypt (8.0-23.9 cm), [24] in Rosetta branch of the Nile River, Egypt $(10.5-24.5 \mathrm{~cm})$, [31]in the Tigris River south of Baghdad, Iraq (3.5-27.9 cm), and [46]in the Shatt Al-Arab River, Basrah, Iraq (10-21.5 cm). However, the size of the species in the present study was lower than those reported from some other waters, such as 10.6-39.8 cm in the Benito Juárez dam, Mexico [47], 20.5-40.9 cm in El Infiernillo Reservoir, Mexico [23], and 13.9-53.8 cm in the Aguamilpa Reservoir, Mexico [25], This may be related to differences among fishing gear used, and to different of ecological condition of these habitats.

Regardless of their sex, all $O$. aureus samples in the present study have positive allometric growth, which indicated that the fish becomes relatively stouter or deeper bodied as it increases in length [48]. This result is comparable with the finding of [22] in Wadi El-Raiyan Lakes, Egypt $(b=3.109)$. The value of $b$ from other studied for this species revealed negative allometric growth, such as 2.77 for males, 2.73 for females and 2.87 for all individuals in the Infiernillo Reservoir, Mexico [23], 2.87 in Rosetta branch of the Nile River, Egypt [24], and 2.56 for males, 2.43 for females and 2.51 for all individuals in the Aguamilpa Reservoir, Mexico [25]. [25] stated that allometric growth is often common in species of the genus Oreochromis, which may be attributed mainly to problems of food, fish density, and sexual dimorphism and behaviour. Such variations in the exponent value may 
depend upon various factors like number of specimens examined, stomach fullness, sex variation, disease and parasite loads, stage of maturity, condition of places of sampling, sampling season etc. [49-51].

The monthly trends in the relative condition factor $\left(\mathrm{K}_{\mathrm{n}}\right)$ of $O$. aureus in the present study revealed that July (summer) was the most favorable time and that the population displays its worst condition in February (winter). Also, the relative condition factor of the investigated species is well-being values during October, April and July for all individuals, these may be related to the feeding activity (feed index) and the gonad development (gonadosomatic index). [25] found that the highest values of the relative condition factor $\left(\mathrm{K}_{\mathrm{n}}\right)$ of O. aureus in the Aguamilpa Reservoir, Mexico occurred during September 2000 and February and May 2001, which were the months with the largest percent of spawning and post-spawning females. The fluctuations in the condition factor of many fish were observed concerning their reproductive cycle, feeding rhythms and other environmental and physiological factors [52-54].

In this study, the scales were used for age determination of $O$. aureus. The use of scales for age determination and growth studies for this species has been shown to be valid [22-24, 31]. The total length-scale radius relationship of $O$. aureus revealed a strong linear correlation. This confirms the validity of using scales for growth assessment [35]. A shorter age was reported for the $O$. aureus to be 3 years in Wadi El-Raiyan Lakes, Egypt [22], and 4 years in the Rosetta branch of the Nile River, Egypt [24]. It was also reported that $O$. aureus, attains an age of 7 years in the Tigris River south of Baghdad [31], and 8 years in the Infiernillo reservoir, Mexico [23]. This can be because of fishing pressure and sampling method.

On the other hand, the fish length of $O$. aureus in the present study at which the scales appear on the body for the first time was $\mathrm{a}=2.47 \mathrm{~cm}$ TL. This result is comparable with the findings of [22] in Wadi El-Raiyan Lakes, Egypt $(\mathrm{a}=2.07 \mathrm{~cm} \mathrm{TL})$, and [24]in the Rosetta branch of the Nile River, Egypt $(\mathrm{a}=2.78 \mathrm{~cm} \mathrm{TL})$.

The theoretical growth in length $(\mathrm{L} \infty)$ of $O$. aureus in the present study was $27.6 \mathrm{~cm}$. Similar results were obtained by [22] for the species in Wadi El-Raiyan Lakes, Egypt $(\mathrm{L} \infty=27.2 \mathrm{~cm})$ and [24] in the Rosetta branch of the Nile River, Egypt $(\mathrm{L} \infty=26.4 \mathrm{~cm})$. The longest values of $\mathrm{L} \infty$ were 47.9 and $43.3 \mathrm{~cm}$ SL reported in the Infiernillo reservoir, Mexico [23], and in the Aguamilpa Reservoir, Mexico [25], respectively. [23] stated that the values of $\mathrm{L} \infty$ fluctuated between 25.7 to $56.8 \mathrm{~cm} \mathrm{SL}$ and $\mathrm{K}$ between 0.11 to 1.37 for $O$. aureus individuals that inhabiting different reservoirs in Mexico, and mentioned that the environmental differences can be more important than genetics for maturation and growth of tilapias, in additional to non-representative sampling and erroneous methodological applications.

The present growth performance index (Ø) of O. aureus was less than observed earlier for this species. [22] recorded the value of $\varnothing$ was 2.62 for the species in Wadi El-Raiyan Lakes, Egypt. [23] stated that the values of $\emptyset$ for $O$. aureus individuals inhabiting different reservoirs in Mexico were 2.20 to 2.97. Moreover, [24] recorded a value of $\emptyset=2.45$ for the species in Rosetta branch of the Nile River, and 2.83 in the Aguamilpa Reservoir, Mexico [25].

Females of $O$. aureus were more abundant than males throughout the year in the present study, except in September, November, and May-July, but the overall sex ratio was 1:1.04 (male: female) and did not differ significantly of the expected ratio $1: 1\left(\chi^{2}=0,02 ; P=0,05\right)$. Several authors have reported dominance of either males or females for $O$. aureus in some months or seasons such as; in the Lake Edku, Egypt, the overall sex ratio (males: females) was 1:1.20 [21]; in the Euphrates River at Al-Hindyah barrier, the overall sex ratio of the species (males: females) was 1.68:1 [29]; in the Tigris River, south Baghdad, the overall sex ratio of O. aureus (males: females) was 1.10:1, and the prevalence of males during the summer and spring, while females during autumn and winter [55]. The sex ratio of fish population changes based on spawning season, the life stage of the fish, spawning ground, fishing area, and migration [56, 57].

No fish less than $6.6 \mathrm{~cm}$ was caught in the present study, and this fish was female at the maturity stage, and the smallest male $(9.2 \mathrm{~cm})$ in the samples was sexually mature. [21] mentioned that the sizes of $O$. aureus in the Lake Edku at first sexual maturity $\left(\mathrm{L}_{\mathrm{m} 50}\right)$ for males and females were 8.2 and $9.2 \mathrm{~cm}$, respectively. [25] stated that the length at which $50 \%$ of $O$. aureus specimens matured $\left(\mathrm{L}_{\mathrm{m} 50}\right)$ was $23 \mathrm{~cm} \mathrm{SL}$, and the smallest mature was 18 $\mathrm{cm}$ SL in the Aguamilpa Reservoir, Mexico.

The GSI indicates gonad development and maturity of fish, therefore the monthly change in GSI was followed in order to determine the time of the spawning season and reproductive behavior [32]. The GSI of the fish increases with the maturation of the fish, being maximum during the peak period of maturity and declining sharply after spawning. Two peaks of the gonado-somatic index (GSI) for O. aureus were showed in the present study, the highest one in April thereafter as a sign of the continuous release of eggs, and the second in September for all 
individuals. This finding is in agreement with those given by [21, 55]. [21] stated that the first peak of GSI $O$. aureus in the Lake Edku, Egypt extended from February to June with a peak in GSI values of 2,17 for males and 6.27 for females in May, and the second peak extended from August to November with maximum GSI values of 1.95 for males and 3.86 for females in October. [55] found two peaks of GSI for the species in the Tigris River, south Baghdad, the highest one in May, and the second in October. [25] stated that the first four months of the year represent the peak reproductive period of O. aureus in the Aguamilpa Reservoir, Mexico when monthly water temperature ranged between 25 and $28.3^{\circ} \mathrm{C}$. [23] mentioned that $O$. aureus have asynchronous spawning, where ovaries do not mature at the same time, but in stages, therefore, the egg liberation takes place sequentially for approximately four months that the spawning period lasts, and the species is a mouthbrooder. The mouth brooder phenomenon for $O$. aureus was clear in the present study (Fig. 9).

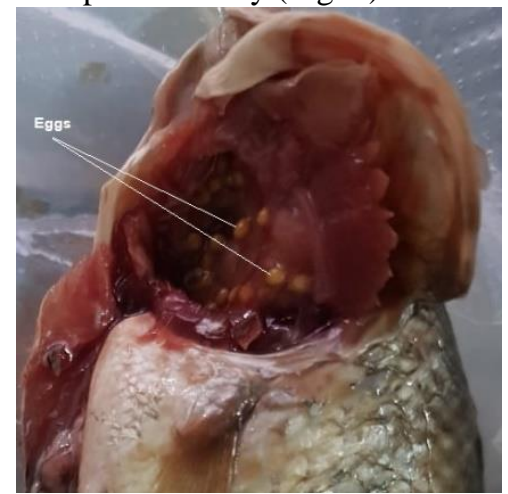

Figure 9: Photograph of $O$. aureus showing the mouthbrooder phenomenon

The fecundity of $O$. aureus in the present study varied from 352 to 1033 eggs when the fish ranges from 12.2 to $20.5 \mathrm{~cm}$ in length and 29 to $165 \mathrm{~g}$ in weight, this result was more or less similar to those reported in the literature about $O$. aureus. [58] stated that the fecundity of $O$. aureus ranged between 97 to 1042 eggs for fish weighted 24 to $117 \mathrm{~g}$, and there was a highly significant positive correlation between fecundity and fish weight $(\mathrm{r}=0.55)$. [21] stated that $O$. aureus was markedly less fertile than $O$. niloticus, having absolute fecundity varied from 310 to 976 eggs in the fish ranging from 9-18 cm TL in Lake Edku, Egypt, while [25] found that the fecundity of O. aureus in the Aguamilpa Reservoir, Mexico ranged from 118 eggs (22.7cm SL) to 5,753 eggs (29cm SL). [55] mentioned that the fecundity of $O$. aureus ranged from 528 to 2,654 eggs for fish of total length ranging between 13.8 to 19.8 $\mathrm{cm}$ TL in the Tigris River, south Baghdad. [59] stated the species that show parental care is characterized by low fecundity and large egg size while those that do not show parental care generally have high fecundity and small egg size.

Despite the results indicated a significant correlation between fecundity of $O$. aureus with both total length and total weight, the results show that the exponent values (b) of the relationship of absolute fecundity with both body parameters were significantly different from the values suggested by [32] and thus the fecundity of $O$. aureus in the present study grows allometrically. However, [25] found no significant relationship was found between the fecundity of $O$. aureus with both fish length (SL) and body weight in the Aguamilpa Reservoir, Mexico. While, [55] found similar results for $O$. aureus in the Tigris River, south Baghdad where $b=2.36$ with total length and $\mathrm{b}=0.78$ with total weight. The variation of fecundity is common across species, and within the same species because of differences in age, body length, gonadal weight and environmental factors [60, 61].

In general, the diet of $O$. aureus in the present study appears to be broadly similar to that of the species found in other locations around the world, fed mostly on plant materials originally. [19] stated that the food items of Tilapia aureus (O. aureus) in the North Carolina Reservoir contained mainly organic and inorganic detritus and large amounts of phytoplankton, and zooplankton and benthic invertebrates comprised only small percentages of the stomach contents in this reservoir. He concluded that this species is an opportunistic feeder that will successfully utilize whatever food source is available. [62] stated that $O$. aureus is an herbivorous feeding mainly on macrophytes, detritus, and microorganisms, and can shift their feeding habits depending on the abundance and composition of foods available in different aquatic environments. [63] stated that Cichlid fish species did not consume food at random but have the ability to select and choose the preferred foodstuff even during different seasons. [26] found that the species consumed macrophytes (45.2\%), detritus (29.4\%) and phytoplankton (16.8\%) in Lake Ziway, Ethiopia. [27] also found that O. aureus consumed macrophytes (45.2\%), algae (31.3\%), detritus $(14.4 \%)$ and diatoms $(4.4 \%)$ in the Shatt Al-Arab River. [28] stated that $O$. aureus fed on macrophytes (49.6\%), algae (25.5\%), diatoms (14.5\%) and detritus (6.3\%) in Chybayish marsh. [55] found that O. aureus ingested detritus $(46.3 \%)$, algae (11.8\%) and macrophytes $(9.3 \%)$ in Tigris River, south of Baghdad. 
These results highlighted basic biological features on invasive O. aureus which can assist in fisheries management and conservation of the fish species in Iraqi waters.

\section{REFERENCES}

[1] William CH. "Evaluation of Blue Tilapia (Oreochromis aureus) for Duckweed (Lemna minor) Control in South Carolina's Private Waters. Ph.D. Dissertation, Clemson University, South Carolina, USA, 2015.

[2] Froese R., Pauly D. "FishBase. World Wide Web electronic publication”. www.fishbase.org, Online Version, Updated 2 January 2019.

[3] McAndrews BJ. "Evolution, phylogenetic relationships and biogeography". In; Beveridge MCM, McAndrews BJ. (eds), Tilapias: Biology and Exploitation. Academic Publishers, Dordrecht, The Netherlands. p. 1-32, 2000.

[4] Popma T, Masser M. “Tilapia Life History and Biology”. Southern Regional Aquaculture Centre, USA, Publication No. 283, 1999..

[5] Canonico GC, Artihington A, McCrary JK, Thieme ML. "The effects of introduced tilapias on native biodiversity". Aquatic Conservation: Marine and Freshwater Ecosystems. vol 15,pp. 463-483, 2005.

[6] Al-Sa'adi BA. "The parasitic fauna of fishes of Euphrates River: Applied study in Al-Musaib city". M. Tech. Thesis, Al-Musaib Technical college Foundation Technical Education. 102 p., 2007.

[7] Saleh KI. "First record of cichlid fish Tilapia zilli in the Euphrates River near Musaib City, Centre of Iraq" (Abstract). $2^{\text {nd }}$ Fisheries Conference, Basrah University, March 1-4, 2007.

[8] Mutlak FM, Al-Faisal AJ. "A new record of two exotic cichlids fish Oreochromis aureus (Steindacher, 1864) and Tilapia zilli (Gervais, 1848) from south of the main outfall drain in Basrah city”. Mesop. J. Mar. Sci., vol 24(2), pp. 160-170, 2009.

[9] Al-Faisal AJ, Mutlak FM. "First record of the Nile tilapia Oreochromis niloticus (Linnaeus, 1758) from the Shatt Al-Arab River, Southern Iraq”. International Journal of Marine Science, vol 5. pp. 1-3, 2015.

[10] Al-Zaidy KJ. "First recorded of Tilapia zilli in AL-Delmj Marsh west AL-Diwania City Middle of Iraq. Diyala Agricultural Sciences Journal., vol 5(1), pp. 9-16, 2013.

[11] Wahab NK. "Food habits and diet overlaps for some freshwater fish in Tharthar Arm, Tigris, Iraq". Basrah Journal of Agricultural Sciences, vol 26(2), pp. 182-197, 2013.

[12] Nasir NA, Farnar KW. "Feeding ecology of zero group fish community from Shatt al-Arab River in Basrah, Iraq". Journal of Arab Gulf Journal for Scientific Research, vol 32(2), pp. 1-9, 2014.

[13] Al-Okailee MTK, Falah M, Lazem LF. "Distribution of redbelly tilapia Coptodon zillii (Gervais, 1848) larvae in Shatt Al-Arab River and East Hammar marsh, Iraq”. Basrah J. Agric. Sci., vol 30(1), pp. 25-31, 2017.

[14] Mohamed ARM, Abood AN. "Compositional change in fish assemblage structure in the Shatt Al-Arab River, Iraq”. Asian Journal of Applied Sciences, vol 5(5), pp. 944-958, 2017.

[15] Mohamed ARM, Younis KH, Hameed EK. "Status of fish assemblage structure in the Garmat Ali River, Iraq”. Global Journal of Biology, Agriculture \& Health Sciences. vol 10(2), pp. 17-22, 2017.

[16] Mohamed ARM, Al-Jubouri MOA. "Fish assemblage structure in Al-Diwaniya River, middle of Iraq". Asian Journal of Natural and Applied Sciences, vol 6(4), pp. 10-20, 2017.

[17] Abdullah AHJ, Abdullah SA, Al-Robayii OA. "Spatial and temporal pattern of sympatric fish assemblage in the Al-Sweib River South of Iraq". Proceedings of the 3rd Agricultural Scientific Conference 5-6 March 2018. The University of Kerbala. p: 1-17, 2018.

[18] Mohamed ARM, Hameed EK. "Impacts of saltwater intrusion on the fish assemblage in the middle part of Shatt Al-Arab River, Iraq”. Asian Journal of Applied Sciences, vol 7(5), pp. 577-586, 2019.

[19] Mallin MA. "The feeding ecology of the blue tilapia (Tilapia aurea) in a North Carolina reservoir". Proceedings of the Conference and International Symposium on Applied Lake \& Watershed Management, vol 5, pp. 323- 326, 1985.

[20] Bakhoum SA. "The food and feeding ecology of Oreochromis niloticus (Linn) and Oreochromis aureus (Steind.) in Lake Mariut, Egypt. Alex. Sci. Exch., vol 16(1), pp. 71-85, 1995.

[21] Bakhoum SA. "Comparative reproductive biology of the Nile Tilapia Oreochromis niloticus (L.), Blue Tilapia, Oreochromis aureus (Steind.) and their hybrids in Lake Edku, Egypt". J. Aquat. Biol. and Fish, vol 6(3), pp. 121-142, 2002.

[22] Mehanna SF. "Population dynamics of two Cichlids, Oreochromis aureus and Tilapia zillii from Wadi ElRaiyn, Lakes, Egypt”. Agric. Mari. Sci., vol 9(1), pp. 9-16, 2004.

[23] Jímenez-Badillo ML. "Age-growth models for tilapia Oreochromis aureus (Perciformes, Cichlidae) of the Infiernillo reservoir, Mexico and reproductive behaviour”. Revista de Biología Tropical, vol 54(2), pp. 277-588, 2006.

[24] Mahmoud MH, Mazrouh MM. "Biology and fisheries management of Tilapia species in Rosetta branch of the Nile River, Egypt”. Egyptian J. Aquat. Res. vol 34 (3), pp. 272-285, 2008. 
[25] Messina EP, Varela RT, Abunader JIV, Mendoza AAO, Arce JM. "Growth, mortality and reproduction of the blue tilapia Oreochromis aureus (Perciformes: Cichlidae) in the Aguamilpa Reservoir, Mexico”. Rev. Biol. Trop. vol 58(4), pp. 1577-1586, 2010.

[26] Dadebo E, Kebtineh N, Sorsa S, Balkew K. "Food and feeding habits of the Red-Belly Tilapia (Tilapia zillii Gervais, 1848) (Pisces: Cichlidae) in Lake Ziway, Ethiopia". Agriculture, Forestry and Fisheries, vol 3(1), pp. 17-23, 2014.

[27] Abdullah AJ. "Fish biodiversity and some biological characteristics in the northern part of Shatt Al-Arab River and some of its reaches". Ph.D. Thesis, Basrah University, Basrah, Iraq. 192p, 2015.

[28] Salah AA. "The morphology of the alimentary canal and related to feeding habits of three fish species in Abu-Julan region, south Al-Chybaish marsh”. MSc Thesis. College of Agriculture, University of Basrah. $121 \mathrm{p}, 2015$.

[29] Hussain TS, Abu Alheni AKJ, Kati AZJ, Hassan SM, Ali SM, Mohsen AM. "Describe the growth of blue tilapia Oreochromis aureus (Steindachner, 1864) in the Euphrates River/Al-Hindyah barrier". Journal of Tikrit University for Agricultural Sciences, vol 17, pp.443-450, 2017.

[30] Abu Alheni AKJ, Hussain TS, Rahij ASM, Shaker HF, Hassan SM. "Feeding overlap between three species of tilapia in the Euphrates River". Journal of Tikrit University for Agricultural Sciences, vol 17, pp. 509-516, 2017.

[31] Attee RS, Abu Alheni AAJ, Khalifa SZ. "Described the growth of in the Tigris River south of Baghdad". University of Thi-Qar Journal of agricultural research, vol 7(1), pp. 153-171, 2018.

[32] Bagenal TB, Braum E. "Eggs and early life history". In: Bagenal, T. (ed.). Methods for assessment of fish production in freshwater, $3^{\text {rd }}$ ed. IBP Handbook No. (3): Blackwell Sci. Publ., Oxford. pp: 165-201, 1978.

[33] Le Cren ED. "The length-weight relationship and seasonal cycle in gonad weight and condition in the perch (Perca fluviatilis)". J. Anim. Ecol. Vol 20, pp. 201-219, 1951.

[34] Ricker WE. "Computation and interpretation of biological statistics of fish populations". Bull. Fish. Res. Board. Can. vol 191, 382 p, 1975.

[35] Bagenal TB, Tesch FW. "Age and growth”. In: Bagenal, T. (ed.). Methods for assessment of fish production in freshwater, $3^{\text {rd }}$ ed. IBP Handbook No. (3): Blackwell Sci. Publ., Oxford, pp: 101-130, 1978.

[36] Pauly D, Munro JL. "Once more on the comparison of growth in fish and invertebrates". ICLARM Fish byte, vol 2, pp, 21, 1984.

[37] De Silva SS. "Aspects of the reproductive biology of the sprats Sprattus sprattus L. in inshore waters of the west coast of Scotland”. J. Fish Biol., vol 5, pp. 689-705, 1973.

[38] Hynes HBN. "The food of fresh water sticklebacks (Gasterosteus aculeatus) and (Pygosteus pungitius) with a review of methods used in studies of food of fishes". Journal of Animal Ecology, vol 19, pp. 36-58, 1950.

[39] Sarkar UK, Deepak PK. "The diet of clown knife fish Chitalachitala (Hamilton - Buchanan) an endangered notopterid from different wiled population (INDIA)”. Electronic Journal of Ichthyology, vol 1, pp. 11-20, 2009.

[40] Maia A, Queiroz J, Correia P, Correia H. "Food habits of the short fin mako, Isurus oxyrinchus, off the southwest coast of Portugal". Environmental Biology of Fishes, vol 77, pp. 157-167, 2006.

[41] Edmondson WT. "Freshwater biology". John Wiley and Sons Inc. New York, 1248pp, 1959.

[42] Hadi RAM, Al-Saboonchi AA, Haroon AKY. "Diatoms of Shatt Al-Arab River, Iraq". Nova Hedwigia, vol 39, pp. 513-557, 1984.

[43] Al-Saboonchi AA, Barak NA, Mohamed ARM. "Zooplankton of Garma marshes, Iraq". J. Biol. Res., vol 17(1), pp. 33-39, 1986.

[44] Hyslop EJ. "Stomach contents analysis -a review of method and their application". Journal of Fish Biology, vol 17, pp. 413-422, 1980.

[45] Stergion KI. "Feeding habits of the Lessepsian migrant Siganus luridus in the Eastern Mediterranean, its new environment". Journal of Fish Biology, vol 33, pp. 531-543, 1988.

[46] Jawad LA, Habbeb FH, Al-Mukhtar MA. "Morphometric and Meristic Characters of Two Cichlids, Coptodon zillii and Oreochromis aureus Collected from Shatt al-Arab River, Basrah, Iraq". International Journal of Marine Science, vol 8(2), pp. 12-24, 2018.

[47] Ramos-Cruz S. "Reproducción y crecimiento de la mojarra tilapia (Oreochromis aureus) en la presa Benito Juárez, Oaxaca, México en 1993. INPSEMARNAP. Ciencia Pesquera vol 11, pp. 54-61, 1995. (Cited in Messina et al., 2010).

[48] Riedel R, Caskey LM, Hurlbert SH. "Length-weight relations and growth rates of dominant fishes of the Salton Sea: implications for predation by fish-eating birds". Lake and Reservoir Management, vol 23, pp. 528-535, 2007. 
[49] Sparre P, Venema SC. "Introduction to tropical fish stock assessment". FAO Fisheries Technical Paper306/1, 1992.

[50] Gokce G, Aydin I, Metin C. "Length-weight relationships of 7 fish species from the North Aegean Sea", Turkey. IJNES., vol 1, pp. 51-52, 2007.

[51] Mili S, Ennouri R, Chhibi M, Laouar H, Romdhane N, Missaoui H. "Length-weight relationships (LWRs) of endemic and introduced freshwater fish species in 13 Tunisian reservoirs". Journal of new sciences, Agriculture and Biotechnology, vol 41(8), pp. 2253-2259, 2017.

[52] Wootton RJ. Ecology of Teleost Fishes". $2^{\text {nd }}$ ed. Kluwer Academic Publishers Dordrecht, London, 396 pp, 1998.

[53] Ahmad Dar S, Najar AM, Balkhi MH, Rather MR, Rupam SR. "Length-weight relationship and relative condition factor of Schizopyge esocinus (Heckel, 1838) from Jhelum River, Kashmir". International Journal of Aquatic Science, vol 3(1), pp. 29- 36, 2012.

[54] De Giosa M, Czerniejewski P, Rybczyk A. "Seasonal changes in condition factor and weight-length relationship of invasive Carassius gibelio (Bloch, 1782) from Leszczynskie Lakeland, Poland". Advances in Zoology, vol 2014, pp. 1-7, 2014.

[55] Khalifa SZ. "Ecological and biological of Nile tilapia Oreochromis niloticus and blue tilapia Oreochromis aureus from Tigris River, Southern Baghdad". MSc. Thesis. College of Agriculture, University of Diyala. $123 \mathrm{p}, 2017$.

[56] Nikolsky GV. “The ecology of fishes”. Academic Press, London and New York, 352 p, 1963.

[57] Mouine N, Ktari MH, Chakroun-Marzouk N. "Reproductive characteristics of Spondyliosoma cantharus (Linnaeus, 1758) in the Gulf of Tunis". Journal of Applied Ichthyology, vol 27, pp. 827-831, 2011.

[58] Aureli TJ, Torrans L. "Spawning frequency and fecundity of blue tilapia". Journal of the Arkansas Academy of Science: vol. 42 , Article 32, 1988.

[59] Jegede OI, Fawole OO. "Fecundity and egg size variation in Tilapia zillii (Gervais) and Tilapia marliae (Boulenger) from Lekki Lagoon, Nigeria”. Ife Journal of Science, vol 13(2), pp. 220-225, 2011.

[60] Lagler KF, Bardach JFZ, Miller RR. "Ichthyology": John Wiley and Sons, Inc, New York, London, Sydney, 59-301, 1967.

[61] Jonsson N, Jonsson B. "Trade-off between egg mass and egg number in brown trout”. Journal of Fish Biology, vol 55, pp. 767-783, 1999.

[62] Al-Jamal A. "Fish Farming". Part 3, Scientific Books House for Publishing and Distribution, Cairo, Egypt, 2006.

[63] Shalloof KA, Authman MN, El-Kasheif MA. "Food and feeding habits of three cichlid species inhabiting Damietta branch of the River Nile, Egypt". Egyptian Journal of Aquatic Biology and Fisheries, vol 13(4), pp. 49-66, 2009. 